\title{
IMPACT OF PRIVATIZATION OF THE NIGERIAN RIVER BASIN AUTHORITIES ON WATER USE EFFICIENCY
}

\author{
Ajiboye Abiodun \\ Senior Lecturer, Department of Agricultural Economics and Extension Services, \\ Ekiti State University PMB 5363, Ado Ekiti, Ekiti State, Nigeria.
}

DOI: 10.46609/IJAER.2020.v06i02.010 URL: https://doi.org/10.46609/IJAER.2020.v06i02.010

\begin{abstract}
The study examined the impact of privatization on efficiency of water use in selected irrigation schemes under the Lower Niger River Basin Development Authority of Nigeria. Government policy is aimed at achieving food self-sufficiency through the proposed privatization of these schemes hence making water an economic good whose use will thus be levied more rationally. Data was drawn on 414 small-scale irrigation farms under the two existing tenure Systems in 7 irrigation schemes in the basin.

The DEA results showed that on the average, substantial overall inefficiencies characterized the farms in both the User Allocation and Farmer Occupier tenure systems. Unlike the situation in the rice farms, vegetable and maize farmers under the Farmer Occupier System demonstrated considerably higher levels of efficiency than those in the other system. For the vegetable farmers, it was a switch of value dominance between the CRSTE and the VRSTE. The result of the price simulation showed an irregular pattern of marginal efficiency change in all the DMUs of both systems. This result frowns at the proposed privatization, should the new investor transact resources in a way that is not at par with the prevailing open market condition thereby overshooting the margins of farm-level efficiency.
\end{abstract}

Keywords: Privatization, River Basin Authorities, DEA, Price Simulation.

\section{List of Abbreviations:}

RBDA: River Basin Development Authority of Nigeria

LNRBDA: Lower Niger River Basin Development Authority of Nigeria

DEA: Data Envelopment Analysis 
International Journal of Agriculture and Environmental Research

ISSN: 2455-6939

Volume: 06, Issue: 02 "March-April 2020"

DMU: Decision Making Unit

CRSTE: Constant Return to Scale Technical Efficiency

VRSTE: Variable Return to Scale Technical Efficiency

UAS: User Allocation System

FOS: Farmer Occupier System

ATA: Agricultural Transformation Agenda

\section{INTRODUCTION}

The rate at which major rivers and lakes are shrinking around the world calls for urgent attention to safeguard the livelihood of millions of people who depend on these water resources especially for fishing and irrigation. For instance, the Lake Chad in north eastern Nigeria, one of the once largest lakes in the world, has reduced by almost $90 \%$ its size over the past 60 years. River Niger, which is the third African largest river, is also rapidly shrinking. With a growing population, it has been predicted that, due to desertification, the Sahara will likely expand farther southward which will increase the pressure on the available water resources. According to the (OECD, 2012) It is projected that between 2000 and 2050, water demand will increase by 55\% globally. It is also projected that by $2050,3.9$ billion people are likely to be living in river basins under severe water stress. Nigeria, with three of its six geopolitical zones located in the savannah, an already water-stressed region, shares its own episode in this ongoing water-food demand nexus. Following the sahelian drought of the early 70,s, the Federal Government of Nigerian created 12 River Basin and Development Authourity (RBDAs) to develop and manage the water resources of the country amongst other complimentary functions, in order to buffer the production risks of farmers especially in key producing basins of the country. Ever since this period it has become very obvious, through the awareness of climate change that water is a limiting factor to agricultural production especially in these drier parts of the country. Since this period also, the allocation and management of water supplies in Nigeria have been predicated upon heavy government subsidies. Land ownership arrangement in these schemes was also altered, leaving behind two major tenure patterns namely the User Allocation and the Famer Occupier tenure systems.

In recent times, the agricultural subsectors is witnessing a new dawn due to the awakened interest of the government in taking the Nigerian economy beyond oil and agricultural sector has hence been receiving a boost and restructuring in other to realize this goal. This leads to the proposal of one of the key policies of this Federal Government which is the Agricultural Transformation Agenda (ATA) of the Nigerian government .One of the major content of this transformation agenda is the proposed privatization which is being backed up by the Federal Government constant campaign of a total ban on staple food import. The aim of this ATA is to 
International Journal of Agriculture and Environmental Research

ISSN: 2455-6939

Volume: 06, Issue: 02 "March-April 2020"

increase the food production in the country to six-fold by 2020. However, the present method of farming system cannot sustain this agenda. Presently, the major means of food production available to the country is expansion of cultivated area which is now being jeopardized due to factors such as Industrial and road needs, urbanization, deforestation, desertification, oil spillage and conflict between crop farmers \& Fulani pastoralists in many communities in the country etc. The major means to attain a rapid increase in food production in conjunction with rain-fed farming is via improvement of irrigation activities in key producing basins of the country. However irrigation farming productivity is being threatened due to climate change, the emerging imbalance between water need and population explosion and also the poor ways resources are being harnessed in these public schemes. Government opines, therefore, that these public schemes will do well if their managements are transferred to the private sector.

The preparedness of the government of Nigeria to privatize the irrigation sector is very palpable. In 2013, government reasserted that the RBDAs will soon be handed over to the private sector to manage because it has largely failed to live up to their mandate in the area of supporting agriculture through irrigation as well as enhancing water supply and power. There was a little hitch, however, when the proposal got to the upper legislative chamber which demanded that the irrigation Acts be first perused before finally releasing the clutch. Between 1999 and 2012 in Nigeria, 122 enterprises had been sold to the private sectors through the Bureau of Public Enterprises (BPE). The Bureau is presently working assiduously towards the privatization of the country's 12 RBDAs and some other institutions including the Bank of Industry and the Bank of Agriculture. While proponents of privatization see this aspect of economic reform as an instrument of efficient resource management for rapid economic development and poverty reduction, the critics argue that privatization inflicts damage on the poor through loss of employment, reduction in income, and reduced access to basic social services or increases in prices. Whatever are the views of the two parties, the only group that has no voice in the matter is the poor who are always at the receiving end. Though privatization in itself is not inherently bad but the poor performance or effectiveness depends on implementation (Nightingale and Pindus, 1997).

Just as product and service prices were heightened appreciably in all the already privatized Institutions in Nigeria, irrigation resources will without any doubt face its own upward price review under the proposed privatization. From the foregoing, according to Speelman et.al (2007), irrigators under this kind of schemes will likely face two new problems in the future. Firstly, less water will be allocated to individual farms, due to the increasing water scarcity and rationality of new owners who may need to expand production or even divert water meant for irrigation to other uses that are more profitable (e.g hydropower generation, industrial and municipal water supply, fishing and tourism etc), and secondly, irrigators will have to pay more for the water they 
International Journal of Agriculture and Environmental Research

ISSN: 2455-6939

Volume: 06, Issue: 02 "March-April 2020"

use, forcing them to decrease quantity consumed per hectare. This will definitely have an impact on the production system and stress the importance of using water in a more efficient way.

Although there have been flurries of literature that explore the analysis of the efficiency of agricultural production in developing countries ( Ajibefun 2008; Haji, 2006; Malana and Malano, 2006; Chavas et al.;2005;Abay et.at,2004;Binam et al.,2004;Dhunguma et al.,2004; Binam et al.,2003; Coelli et al.,2002, Wadud and White, 2001) most of them have been conducted with little reference to irrigation. Among those that have specifically addressed the efficiency of irrigation water use are: (Somanathan and Ravindranath 2006; Chebil et. al. 2010; Arun et.al. 2012; Speelman 2008; Frija et. al. 2010; Banerji et.al. 2010; Somanathan et.al. Arun et.al. 2012). This study contributes to the growing literature on water efficiency at the farm levels by measuring not just the overall efficiencies but also estimating the potential impact of an increased water price on farm level efficiency. Examining this, in a twin-period survey, under two different tenure systems that are faced with a dawning future of increased water tariffs, is a novelty about this work. To the best of our knowledge, this is the first study in Nigeria that will be peeping into this dimension of irrigation studies. Specifically, we attempt to answer the following two questions: What are the overall efficiency measures of irrigation resource use, and secondly, what impact will the proposed privatization of the RBDAs have on the farmers' efficiencies? The rest of the paper is organized thus: The later part of section 1 talks about the brief description of the tenure systems in the Nigerian RBDAs. Sector 2 gives a brief description of the DEA model, while the second part of this section explains the reasoning behind the simulation of water pricing on efficiency and the third part briefly defines the variables for the analyses. Section three talks about the data. Section 4 discusses the result of the analyses and the conclusion and policy issues are given in the fifth section.

\section{Nature of tenure System in the Nigerian RBDAs}

The system of Land use that exists in the chosen irrigation schemes under the RBDA is quite different from what operates in the farming communities outside the jurisdiction of the RBDA. Presently, two types of land tenure system exist in the Nigerian RBDA, namely the User Allocation System (UAS) and the Farmer Occupier System (FOS). This is as a result of the partial alteration of the existing systems of land ownership by the Federal Government through the Federal Ministry of Agriculture and Water Resources when all the lands belonging to the RBDA were being acquired throughout the country after the sahelian drought of the early 1970s. When the dams in all the six geopolitical zones of the country were being constructed all the lands were acquired by the decree of the then military government and compensation were paid to the affected persons who were the original landlords while many of the communities were relocated. In the User Allocation System, the RBDA acting on behalf of the federal government 
International Journal of Agriculture and Environmental Research

ISSN: 2455-6939

Volume: 06, Issue: 02 "March-April 2020"

of acquires the schemes land demarcates the land into irrigable plots and allocates the plots to interested farmers usually on seasonal or annual basis. Farmers under this tenancy condition are called 'landless farmers' who do not have any right to plant the crop of their choice but must submit to the order of the authority. Farmer Occupier tenure system returns the ascertained original farmers holding to the farmer after the development of the scheme less a percentage use for the provision of the basic infrastructural development. Therefore, Government did not acquire both sides of the rivers but relinquished the one sides from which reservoirs were built for the use of the communities to avoid further communal disputes which erupted during the years of land acquisition in the North -West at the Sokoto Rima and Hadejia Jama'Are RBDAs. Farmers under the farmer occupier system are not registered with the LNRBDA authority for land allocation, but they make use of the water belonging to the RBDA in their irrigation farming and pay water rates just as those under the user allocation systems. In the user allocation system, plots are allocated to individuals based on his/her capacity. Plots are allocated based on the total number of hectares the LNRBDA wishes to cultivate in a particular season. In principle, the mechanism of plot allocation is based on 'first-come, first-serve'. The size of farm allocated to a particular farmer depends on the capacity of the farmer to handle the farm from planting date to harvesting. The location and the fertility status of the plot allocated to a farmer is a random choice.

\section{MATERIAL AND METHOD}

Data envelopment analysis (DEA) was used in this study. The DEA model could be input oriented or output -oriented under either the assumption of Constant Return to Scale CRS or Variable Return to Scale VRS specifications .Our study focused on the input orientation because our interest is to analyse how input is used efficiently. According to Coelli (1996), the best way to introduce DEA is via the ratio form. For each DMU, a measure of the ratio of all outputs over all inputs could be obtained, such as $u^{\prime} y_{i} / v^{\prime} x_{i}$, where $\mathrm{u}$ is an $\mathrm{M} \mathrm{x} 1$ vector of output weights and $\mathrm{v}$ is a $\mathrm{K} \times 1$ vector of input weights. To select optimal weights the following mathematical programming problem is specified:

$$
\begin{aligned}
& \max _{u v}\left(u^{\prime} y_{i} / v^{\prime} x_{i}\right), \\
& \text { s.t } \quad u^{\prime} y_{i} / v^{\prime} x_{i} \leq 1, \quad \mathrm{j}=1,2, \ldots \ldots \ldots \mathrm{N}, \\
& \mathrm{u}, \mathrm{v} \geq 0 .
\end{aligned}
$$

The aim is to determine the values of $u$ and $v$ that will maximized the efficiency index of the $i$-th DMU. The condition is that all efficiency measures must be less than or equal to unity. One 
problem with this particular ratio formulation is that it has an infinite number of solutions. To avoid this, one can impose the constraint $\mathrm{v}^{\prime} \mathrm{x}_{\mathrm{i}}=1$, which provides:

$$
\begin{aligned}
& \max _{\mu, \mathrm{v}}\left(\mu, \mathrm{y}_{\mathrm{i}}\right), \\
& \mathrm{st} \quad \mathrm{v}^{\prime} \mathrm{x}_{\mathrm{i}}=1, \\
& \mu^{\prime} \mathrm{y}_{\mathrm{j}}-\mathrm{v}^{\prime} \mathrm{x}_{\mathrm{j}} \leq 0, \mathrm{j}=1,2, \ldots . \mathrm{N}, \\
& \mu, \mathrm{v} \geq 0,
\end{aligned}
$$

Where the notation change from $u$ and $v$ to $\mu$ and $v$ reflects the transformation. Using the duality in linear programming, the equivalent envelopment form of this problem is:

$$
\begin{aligned}
& \operatorname{Min}_{\theta, \lambda} \theta, \\
& \text { st } \quad-\mathrm{y}_{\mathrm{i}}+\mathrm{Y} \lambda \geq 0, \\
& \\
& \quad \theta \mathrm{x}_{\mathrm{i}}-\mathrm{X} \lambda \geq 0, \\
& \\
& \lambda \geq 0,
\end{aligned}
$$

where $\theta$ is a scalar and $\lambda$, is a $\mathrm{N} \mathrm{xl}$ vector of constants. This envelopment form involves fewer constraints than the multiplier form $(\mathrm{K}+\mathrm{M}<\mathrm{N}+\mathrm{l})$, and hence is generally the preferred form to solve. The value of $\theta$ obtained will be the efficiency score for the i-th DMU. It will satisfy $\theta \leq 1$, with a value of 1 indicating a point on the frontier and hence a technically efficient DMU.

An extension of the CRS DEA to VRS model can be made (Banker, Charnes and Cooper(1984). This will permit the calculation of TE devoid of these Scale effects.

This is done by adding the convexity constraint: N1 ' $\lambda,=1$ to equation (3) to provide:

$$
\begin{array}{ll}
\min & \theta, \lambda \\
\text { st } \quad-\mathrm{y}_{\mathrm{i}}+\mathrm{Y} \lambda \geq 0, \\
& \theta \mathrm{x}_{\mathrm{i}}-\mathrm{Y} \lambda \geq 0, \\
& \mathrm{~N} 1^{\prime} \lambda=1 \\
& \lambda \geq 0,
\end{array}
$$

Where NS is an Nxl vector of ones.

In order to use the DEA to isolate the issue of water use efficiency, the idea of sub-vector efficiency (of water) will be introduced. The efficiency of a single input (water) will be calculated by holding all the other vector of inputs constant. (Speelman et. al. (2008), Frija et. al 
(2010) and Chebil et. al. (2010). Oude Lansink and Silva, 2004; Oude Lansink and Silva, 2003; Oude Lansink et al., 2002; Färe et al., 1994).This is describe in equation 5 below

$$
\begin{array}{ll}
\operatorname{Min}_{\theta \lambda} \theta^{k}, & \\
s t & -y_{i}+Y \lambda \geq 0, \\
& \theta^{k} x_{i}^{k}-X^{k} \lambda \geq 0, \\
& x_{i}^{n-k}-X^{n-k} \lambda \geq 0, \\
& N 1^{\prime} \lambda=1 \\
& \lambda \geq 0
\end{array}
$$

Where $\theta^{k}$ is the input $\mathrm{k}$ sub-vector efficiency score of water for farm $\mathrm{i}$. The term $x_{i}^{n-k}$ and $X^{n-k}$ in the third constraint refer to $\mathrm{x}_{\mathrm{i}}$ and $\mathrm{X}^{\mathrm{k}}$ with the kth input column excluded, whereas in the second constraint, the terms $x_{i}^{k}$ and $X^{k}$ include only the kth input.

Given the price information of the six explanatory variables namely water, land, labour, fertilizer seed and herbicide, the allocative efficiency (AE) and Economic Efficiency (EE) will be calculated. For the case of VRS cost minimization, the input-orientated DEA model can be obtained .This will involve running the following, cost minimization DEA

$$
\begin{aligned}
& \min _{\lambda, x i^{*}} w_{i}^{\prime} x_{i}^{*}, \\
& s t \quad-y_{i}+Y \lambda \geq 0 \\
& N 1^{\prime} \lambda=1 \\
& \lambda \geq 0
\end{aligned}
$$

Where $w_{i}$ is a vector of input prices for the $\mathrm{i}$-th DMU and $\mathrm{x}^{*}$ is the cost-minimizing vector of input quantities for the $\mathrm{i}$-th DMU, given the input prices $\mathrm{w}_{\mathrm{i}}$ and the output levels $\mathrm{y}_{\mathrm{i}}$. The total economic efficiency of the i-th DMU will be calculated as the ratio of minimum cost to observed cost.

$$
E E=\frac{w_{i}^{\prime} x_{i}^{*}}{w_{i}^{\prime} x_{i}}
$$

One can then calculate the allocative efficiency residually as

$$
\mathrm{AE}=\mathrm{EE} / \mathrm{TE} .
$$


International Journal of Agriculture and Environmental Research

ISSN: $2455-6939$

Volume: 06, Issue: 02 "March-April 2020"

\section{Calculating the effect of price increase}

After calculating the efficiency indices, the effect of the increase in some of the input prices as a result of future subsidy removal was calculated. For a better understanding of this section, we have to accentuate it that water was not volumetrically metered out to farmers at the LNRBDA and the present water fee was fixed since several years ago. At the LNRBDA, Farmers have unlimited access to use water on any irrigation day without any restraint from the water wardens. This, however, is anticipated to change if the Nigerian irrigation sub-sector bill presented in Senate sometimes ago is successfully passed. The most practicable method for us to achieve our simulation is to consider the input subsidy regime and the era of subsidy removal as a result of the proposed privatization. We assume quite well that this new irrigation resource owner cannot raise irrigation input prices above what obtains in the open agricultural input market, like in the case of Fadama irrigation and other private irrigation schemes in the country. Any upward price review higher than this deserves a further deliberation. At the LNRBDA, there are presently three categories of input subsidies available to the farmers which make the input prices to be considerably lower than what obtains at the open market. These inputs include land, water and fertilizer. Land charges was a token of N2500 per ha and this price has been fixed over a decade ago without any review up till date. The same land rent at the real agricultural input market in Nigeria is upwards of N7000 per ha for a single seasonal cultivation, depending on the location. Water rates, fixed more than decades ago, remained a preposterous low amount of N500 per Ha. From the perspective of the water wardens and reflecting what obtained in other irrigation subsector in the country, water rate per season should be an upwards of N5000 per season. Under the Growth Enhancement Scheme (GES) and the Agricultural Transformation agenda (ATA), fertilizer is sold to the farmers in both institutional settings at the rate of N3500. Open market price for fertilizer, however is doubled this amount in the country. In this simulation, we did not make any adjustment to the original model. The first dataset was used to generate the first efficiency indices. The second sets of efficiency indices we calculated were based on the fact that rationalities of irrigation resource owners were considered. This means that input prices reflected directly what obtain at the real market during the era of privatization. The DEA model used to generate the first sets of efficiency indices was also used to generate the second sets with the newly generated data. The differences between the efficiency indices at these two periods were then obtained to know the impact of input price increase on farmers' efficiency.

\section{Definition of variables}


International Journal of Agriculture and Environmental Research

ISSN: 2455-6939

Volume: 06, Issue: 02 "March-April 2020"

Six crops altogether were cultivated in the schemes under both tenure conditions the last season. These are Maize, rice and four vegetables. The four vegetable crops are okra, tomatoes, watermelon and leafy vegetable. Some of the vegetable farmers did not follow the pattern of sole cropping as in the case of the grains. For the purpose of convenience we have grouped together all the vegetable farms in each tenure system in all the schemes. For the DEA analysis of these DMUs; outputs, fertilizer, herbicide, pesticide, and Seed were converted to monetary unit i.e the Naira value. Land was measured in Ha, water in $\mathrm{m} 3$ and Labour in Man-day.

\section{Data}

Plot -level irrigation water use estimation and subsequent household interview were carried out in the chosen schemes. Multi-stage stratified sampling procedure was employed. This eventually led us to a random selection of 320 farmers operating 414 farms because some had two plots, from each of these schemes shared among the two types of tenancy arrangements that existed in the schemes.

To estimate water consumption, we adapted the method of Banerji et. al. (2010) and Baljinder et.al.(2010).They computed irrigation water-use for each farm by estimating the monthly irrigation hours and multiplying it with the volume of water drawn out per hour by the motorised pumps based on the capacity of the pump .We used the following formula to arrive at the quantity of water farmers consumed: Qwater=It x Pc. Where, Qwater is the total quantity of water used by farmers throughout the season. It is the total number of times irrigation was done before harvest (hours) i.e the number of hours each day multiply by the total numbers of days. Pc is the Pump capacity (liter/hour). Qwater was later converted to the $\mathrm{m} 3$ equivalent.

The data collection was divided into two periods namely, the plot level data collection which enabled us to reasonably estimate the amount of water the small farmers used by direct pumping. The second is the household survey which was carried out after harvest. Field level data collection started in late December 2013 at the beginning of the irrigation season and ended in March ending/early April 2014 after all crops were harvested. Irrigation officials went round to collect water fees at on-farm levels but there are no legal means or enforcement agencies to back up the collection process. In all the schemes, apart from Oke-Oyi, water was distributed from the reservoir to the field through a canal system where control is turned to the individual farmer. Number of hours spent by farmers to pump water depended on the size of plot to irrigate and ability to fuel the pump. Pump capacity and record of hours spent in pumping water were taken by the irrigation officials in each of the schemes. This was what we used in our water use estimation. 
International Journal of Agriculture and Environmental Research

ISSN: $2455-6939$

Volume: 06, Issue: 02 "March-April 2020"

During the interview, information was gathered on the irrigation schemes included: household characteristics, farm and non-farm activities, quantities and costs of inputs used in production (capital, variable and overhead), volume and value of output, the quantity of water consumed, water demand characteristics and irrigation practices.

\section{RESULTS AND DISCUSSION}

\section{The DEA Results}

Both the CRS and VRS specifications under the input orientation of the DEA models were calculated to get the technical, allocative and economic efficiencies. Only the sub-vector Technical Efficiency of water under CRS and VRS were calculated to enable us monitor how efficiently water was used in the chosen schemes. The program DEAP (Coelli, 1996) was used in these analyses. Separate analyses of these were done for each crop identified in all the schemes, under the two major tenancy conditions that prevailed by pooling farms that cultivated the same crop together in all the seven schemes.

The results of the DEA analyses as shown in tables 2a-2c, revealed that considerable inefficiencies occurred among the irrigation farmers in both tenancy systems for all the crops. For the Rice farmers under the user allocation tenancy system, CRS Technical Allocative and Economic Efficiencies are 0.85, 0.68 and 0.58 respectively. While under the VRS, they are respectively $0.92,0.82$, and 0.75 . Under the prevailing conditions, about $13 \%$ of the rice farmers were fully technically efficient under the CRS while $33 \%$ of the farms were technically efficient under the VRS. The lower levels of AE and EE under both specifications suggests that there is the possibilities for farmers to minimize cost by considering more deeply the relative input prices when input quantities are been selected. This result might be due to the lack of policy incentive, as a result of the water subsidy that should have encouraged farmers to use water more efficiently. It is possible that this may improve in the coming years of privatization or when government decide to meter out irrigation water rather than on a per hectare seasonal charge that presently exists in all the RBDAs.

Under the farmer occupier system, values of the CRS technical, allocative and economic efficiency indices are $0.77,0.68$ and 0.53 respectively while for the VRS they are respectively $0.90,0.72$ and 0.71 . All of these values are observed to be lower than what obtains under the User Allocation. The only exception is the CRS AE which is the same in value under the two systems. This result suggests that rice farmers under the User Allocation demonstrated a moderately higher level of efficiencies in the use of overall inputs. 
For the maize farms, under the user Allocation System overall CRS TE, AE and EE are 0.88, 0.69 and 0.60 while under the VRS they are $0.95,0.79$ and 0.74 respectively. Under the Farmer Occupier system, the average CRS TE, AE and EE are 0.95, 0.72 and 0.68 while the values under the VRS are respectively $0.97,0.74$ and 0.72 .

For the vegetable farm, the CRS TE, AE and EE values under the User allocation are 0.89, 0.61 and 0.54. The VRS values are 0.93, 0.70 and 0.65 respectively. Lastly, under the Farmer Occupier system, the CRS TE, AE and EE are respectively 0.95, 0.39, and 0.39.Values of these under the VRS are 0.96, 0.49 and 0.47.

From these analyses, it can be seen that on the average substantial inefficiencies characterized the farms in both systems. However, unlike the situation among the rice farms, vegetable and maize farmers under the Farmer Occupier system demonstrated considerably higher levels of efficiency than those in the User allocation systems. This may seem to contradict expectations about the performances of these groups. It would be logical to assume that in all the three category of crops identified among the two systems, farmers who are directly under the government should demonstrate higher levels of performance. It all depends on the irrigation pedigree of each of the farmers that constitute these groups. It is possible that there might be switching of systems among some of these farmers so that technologies that exist in one group is not strange to the other, since there is no barrier to exit or entry except for those who were not able to get allocation under the User Allocation System. Or due to the closeness of interaction among these farmers exchange of ideas might be commonplace. Nevertheless, it is of note that in terms of water use, both groups need to be more disciplined. 
Table 2a: DEA results for the rice farms

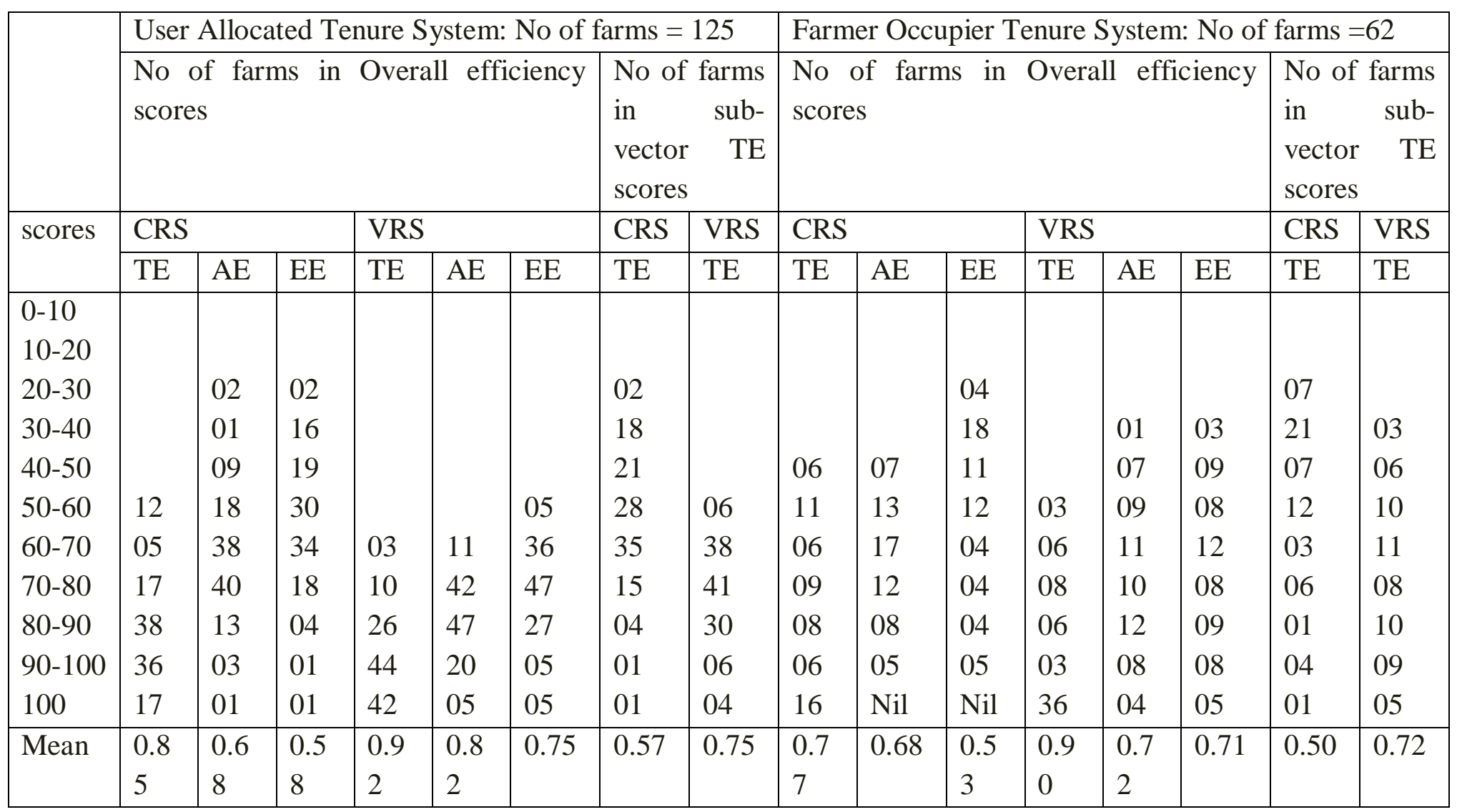


Table 2b: DEA Results for the Maize Farms

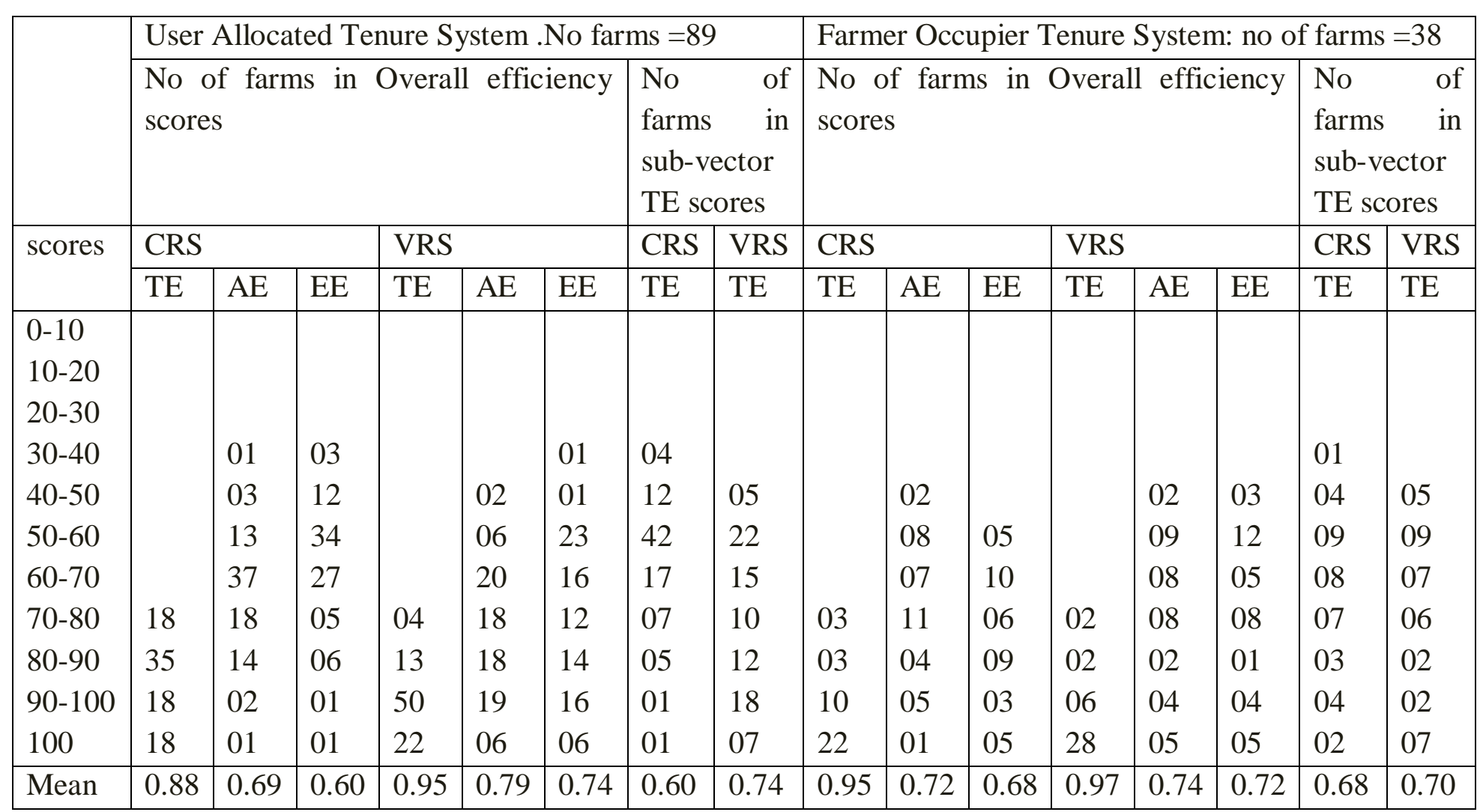


Table 2c: DEA Results for the Vegetable Farms

\begin{tabular}{|c|c|c|c|c|c|c|c|c|c|c|c|c|c|c|c|c|}
\hline & User & Alloc & ted T & nure $S$ & stem & No far & $\mathrm{ms}=5$ & & Farm & er Oc & upier T & enure & Syster & : no o & farms & $=45$ \\
\hline & $\begin{array}{l}\text { No } \\
\text { score }\end{array}$ & f far & in & Overa & effi & iency & $\begin{array}{l}\text { No } \\
\text { farms } \\
\text { sub-v } \\
\text { TE sc }\end{array}$ & $\begin{array}{l}\text { of } \\
\text { in } \\
\text { ector } \\
\text { ores }\end{array}$ & $\begin{array}{l}\text { No } \\
\text { score }\end{array}$ & $f$ far & is in & Overal & effic & iency & $\begin{array}{l}\text { No } \\
\text { farms } \\
\text { sub-v } \\
\text { TE sc }\end{array}$ & $\begin{array}{l}\text { of } \\
\text { in } \\
\text { octor } \\
\text { ores }\end{array}$ \\
\hline scores & CRS & & & VRS & & & CRS & VRS & CRS & & & VRS & & & CRS & VRS \\
\hline & $\mathrm{TE}$ & $\mathrm{AE}$ & $\mathrm{EE}$ & TE & $\mathrm{AE}$ & $\mathrm{EE}$ & $\mathrm{TE}$ & $\mathrm{TE}$ & $\mathrm{TE}$ & $\mathrm{AE}$ & $\mathrm{EE}$ & $\mathrm{TE}$ & $\mathrm{AE}$ & $\mathrm{EE}$ & $\mathrm{TE}$ & $\mathrm{TE}$ \\
\hline $0-10$ & & 01 & 01 & & & & & & & 01 & 01 & & 01 & 01 & & \\
\hline $10-20$ & & & & & & & & & & 04 & 05 & & 02 & 02 & & \\
\hline $20-30$ & & & & & 01 & 01 & & & & 11 & 11 & & 03 & 04 & & \\
\hline $30-40$ & & 01 & 05 & & & 02 & 12 & 09 & & 07 & 08 & & 10 & 10 & 01 & 01 \\
\hline $40-50$ & & 10 & 20 & & 04 & 09 & 13 & 10 & & 07 & 05 & & 06 & 07 & 04 & 01 \\
\hline $50-60$ & 02 & 18 & 12 & 01 & 10 & 11 & 09 & 10 & & 10 & 09 & & 09 & 09 & 13 & 04 \\
\hline $60-70$ & 06 & 10 & 06 & 03 & 13 & 12 & 14 & 10 & & 04 & 04 & & 10 & 09 & 09 & 03 \\
\hline $70-80$ & 06 & 07 & 05 & 05 & 12 & 08 & 02 & 06 & 02 & 01 & 01 & 02 & 02 & 01 & 04 & 09 \\
\hline $80-90$ & 06 & 07 & 06 & 06 & 08 & 06 & 03 & 06 & 04 & & & 04 & & & 08 & \\
\hline $90-100$ & 15 & 01 & & 08 & 05 & 05 & 01 & 01 & 17 & & 01 & 16 & 01 & 01 & 05 & 25 \\
\hline 100 & 20 & & & 32 & 02 & 01 & 01 & 03 & 22 & & & 23 & 01 & 01 & 01 & 02 \\
\hline Mean & 0.89 & 0.61 & 0.54 & 0.93 & 0.70 & 0.65 & 0.55 & 0.60 & 0.95 & 0.39 & 0.39 & 0.96 & 0.49 & 0.47 & 0.69 & 0.86 \\
\hline
\end{tabular}


International Journal of Agriculture and Environmental Research

ISSN: $2455-6939$

Volume: 06, Issue: 02 "March-April 2020"

\section{Price simulation results}

Our price simulation result is shown in table 3. The simulation assumed that output remained unchanged before and during the two periods while the prices of all the three inputs that were subsidized were adjusted in the new data set. The result shows an uneven pattern of marginal efficiency change in response to the input price increase as a result of potential subsidy withdrawal expected to start during the regime of privatization in all the DMUs of both tenure systems. Here, some farms experienced marginal increase or decrease while some maintained their original levels of efficiency as this was the case for the technical efficiencies of all the crops in the two systems. The marginal change was experienced only on the allocative and economic efficiencies of the crops in the two systems. In all the DMUs, the number of farms that experienced a marginal increase in allocative and economic efficiencies was less than those that experienced marginal decrease .The reverse is the case, however, for the UAS vegetable farms and FOS rice farms under CRS specification.

This result might be as a result of the return to scale differentials among the DMUs and indicates that the coming privatization will undermine the viability of poorer performers because the additional cost will mostly affect them. The result showed that most of the farmers will have more difficulty in resource allocation under the proposed subsidy withdrawal. These farmers will have to cut down on the input quantities they used in other to remain relevant in production. Hence, output is expected to reduce as well. This input quantity reduction, however will not apply to water, because of the current technology of water sales at the RBDA.

The manner the subsidy removal will curb excessive water use and hence improve technical efficiency is yet uncertain. This is because it is yet unknown whether or not the new investor will maintain the current method of water sales or change the technology to a volumetric approach. Also, the future decision of the farmers to reduce or improve on fertilizer use is yet not known. This is because it is also uncertain whether government will act according to the promise of provision of a single-digit interest rate loan that is design to boost the financial status of the farmers and cushion the effect of the proposed fertilizer subsidy removal. 
International Journal of Agriculture and Environmental Research

ISSN: 2455-6939

Volume: 06, Issue: 02 "March-April 2020"

Table 3: Price Simulation Table

\begin{tabular}{|c|c|c|c|c|c|c|c|c|c|c|c|c|}
\hline \multirow[t]{3}{*}{ Crops } & \multicolumn{6}{|c|}{$\begin{array}{l}\text { User Allocation System } \\
\text { No of farms in efficiency change }\end{array}$} & \multicolumn{6}{|c|}{$\begin{array}{l}\text { Farmer Occupier System } \\
\text { No of farms in efficiency change }\end{array}$} \\
\hline & \multicolumn{3}{|c|}{ VRS } & \multicolumn{3}{|c|}{ CRS } & \multicolumn{3}{|c|}{ VRS } & \multicolumn{3}{|c|}{ CRS } \\
\hline & TE & $\mathbf{A E}$ & EE & TE & $\mathbf{A E}$ & $\mathbf{E E}$ & TE & $\mathbf{A E}$ & EE & TE & $\mathbf{A E}$ & EE \\
\hline Rice & & & & & & & & & & & & \\
\hline Increase & 0 & 15 & 14 & 0 & 06 & 03 & 0 & 14 & 14 & 0 & 48 & 47 \\
\hline Decrease & 0 & 90 & 88 & 0 & 110 & 114 & 0 & 41 & 41 & 0 & 14 & 13 \\
\hline No change & 125 & 20 & 23 & 125 & 09 & 08 & 62 & 07 & 07 & 62 & 0 & 02 \\
\hline Maize & & & & & & & & & & & & \\
\hline increase & 0 & 21 & 20 & 0 & 15 & 12 & 0 & 0 & 0 & 0 & 05 & 05 \\
\hline Decrease & 0 & 57 & 56 & 0 & 66 & 63 & 0 & 34 & 34 & 0 & 31 & 31 \\
\hline No change & 89 & 11 & 13 & 89 & 08 & 14 & 38 & 04 & 04 & 38 & 02 & 02 \\
\hline Vegetables & & & & & & & & & & & & \\
\hline Increase & 0 & 42 & 41 & 0 & 37 & 37 & 0 & 18 & 18 & 0 & 18 & 18 \\
\hline decrease & 0 & 12 & 13 & 0 & 17 & 17 & 0 & 26 & 26 & 0 & 26 & 26 \\
\hline No change & 55 & 01 & 01 & 55 & 01 & 01 & 45 & 01 & 01 & 45 & 01 & 01 \\
\hline
\end{tabular}

\section{CONCLUSION AND POLICY ISSUES}

The study employed the use of DEA to measure the overall Technical, Allocative and Economic efficiencies of dry season irrigation farmers in the Lower Niger River Basin Development Authority, under the VRS and CRS specifications, among irrigation farmers operating under two different tenure conditions. In order to estimate the possible effect of the proposed privatization of the RBDAs on farmers' efficiencies, an adjustment was made to the original data employing also the initial VRS and CRS models of DEA for the analyses. From our analyses, there existed substantial levels of overall inefficiencies in the use of resources among the irrigation farmers in both tenancy systems for all the crops.

Our simulation is about the effect of price increase of three key inputs which are currently subsidised in all the schemes. Of all these three inputs, water is the most elemental in an irrigation sub-sector like the RBDA where dry season irrigation is not supplemental. This is not just because without it there will be no irrigation and farmers can carry out rain-fed cultivation outside the jurisdiction of the LNRBDA even without fertilizer, but also because it is a foremost public good that people duly esteemed to be free. 
International Journal of Agriculture and Environmental Research

ISSN: 2455-6939

Volume: 06, Issue: 02 "March-April 2020"

The result shows an inconsistent pattern of marginal efficiency change in response to the price increase in all the DMUs of both tenure systems, with some farms experiencing marginal increase or decrease while some maintained their original levels of efficiency. From these results, it is very obvious that since most of the farmers became worse off in terms of allocative and economic efficiencies in all the DMUs after the adjustment made to the data, water pricing and withdrawal of other input subsidies as a new irrigation policy in Nigeria, may not be an effective instrument of achieving the desired outcome of improving efficiency. We acquiesce that in the coming days of privatization, irrigation input prices will assume an upward movement and farmers will have to be more rational in their production decisions. Any upward adjustment of these irrigation input Prices, however, that will be higher than what prevail in the open agricultural input market and also have an impact beyond the margins on efficiency is not advisable in terms of the economic well-being of the farmers.

The Nigerian strategy is that water price may not be increased sharply at the wake of the privatization, though. This is predicted to be sustained through a periodical partial increase until the actual price the company has in mind is established, just as the Power Holding Company of Nigeria did in the country. The fear that irrigators should entertain in Nigeria is not just that government will eventually privatize the RBDAs and prices will increase but that technical hitches may set in if government decide to sell the irrigation institution that control this primary natural resource to those who don't have agricultural development in mind. We mean people who are shareholders in the already privatized hydropower distribution companies of the country and that share the same natural resource base with the RBDAs. Irrigation farmers may not have much problem if future input price is reasonably increased and it is at par with what obtains in the open market. Problems may arise, however, when water management issues that presently exist in some hydropower stations is transferred to the irrigation sub-sector. And we know certainly that the irrigation arm stands to be at a disadvantage because of issues relating to payment.

We propose therefore that if water pricing fails to achieve its purpose of curbing excessive water use and reasonably heightening efficiency, government should try complementary policy alternatives that will favour a moderate use of water amongst these farmers without jeopardizing their welfare. Although, privatization has been a method of making cheap money that cannot be accounted for by the Nigerian government over the years, seeking to maximize the immediate gains of the Nigerian irrigation sector through privatization, however, without due consideration of those that will bear the brunt may turn out to be a heinous crime against humanity as it struggles to emerge out of its up-till-date oblivion. 
International Journal of Agriculture and Environmental Research

ISSN: 2455-6939

Volume: 06, Issue: 02 "March-April 2020"

Furthermore, the nature of water as a public good will not allow the theory of negatively sloped demand curve to purely hold here even though the new investor decide to meter out water volumetrically. Farm level adjustment of water quantity use to a price augment, therefore, cannot be done with the exactness of mathematics. Thus, government should have a rethink about the public irrigation privatization bill that was almost passed in the last senate. Proper consultations should be made across well-meaning institutions and groups in the country before the RBDA is finally handed over to the private investors. These include the Water User Associations, NGOs that have to do with water-related issues, Agricultural and agribusiness companies. Finally town hall meetings could be held across the country to ruminate on this fundamental issue for the benefit of both government and the people.

On the research side, we suggest that other studies that will probe to the willingness to pay for an increased water price among these groups are needed so as to synchronize this efficiency study in informing proper pricing mechanism to discipline water use in the Nigerian RBDAs. Above all, methodologies to modelling the attitudes of the farmers themselves is very important to determine what the situation will exactly look like when the Nigerian RBDA is eventually privatized.

\section{ACKNOWLEDGEMENT}

The Author acknowledges and appreciates the financial and technical support provided by the Center for Environmental Economics and Policy in Africa (CEEPA), University of Pretoria. Any error in this paper, however, is the author's

\section{REFERENCES}

Abay, C. Miran, B, Gunden, C., (2004). "Analysis of Input use efficiency in Tobacco production with respect to sustainability: The case study of Turkey ? "Journal of Sustainable Agriculture"24(3):123-143

Ahaneku I.E. (2010): Conservation of soil and water resources for combating food crisis in Nigeria. Scientific Research and Essays Vol. 5(6), pp. 507-513.

Afikorah-Danquah, S. (1997): Local Resource Management in the Forest -Savannah. Transition Zone: The case study of Whenchi District, Ghana IDS Bulletin 28 (4):163-184.

Ajibefun I.A. (2008): an evaluation of parametric and non-parametric methods of technical efficiency measurement: Application to small -scale food production in Nigeria. Journal of Agriculture and Social Sciences Vol. 4 pp 95-100. 
International Journal of Agriculture and Environmental Research

ISSN: 2455-6939

Volume: 06, Issue: 02 "March-April 2020"

Arun G., Dharam R.S, Shiv K. and Anil K. (2012) Canal irrigation management through water users associations And its impact on efficiency, equity and reliability in Water use in tamilnadu Agricultural Economics Research Review Vol. 25, pp 409-419

Baljinder K., R.S. Sidhu and V. Kamal (2010) "Optimal Crop Plans for Sustainable Water Use in Punjab" Agricultural Economics Research Review Vol. 23, pp 273-284

Banker, R.D., Charnes, A. and Cooper, W. W.(1984). Some Methods for Estimating Technical and Scale Inefficiencies in Data Envelopment Analysis. Management Science 30: 10781092

Barnes A.P., (2006) Does multi-functionality affect Technical Efficiency? A non-parametric analysis of the Scottish dairy industry. Journal of environmental Management. 80.287294.

Besley T. (1995): Property Rights and Investment Incentive: Theory and Evidence from Ghana. The Journal of Political Economy 103:903-937

Binam, J.N., Sylla, K., Nyambi G., (2003) factors affecting technical efficiency among coffee farmers in Coted'voire: Evidence from the center west region. R\&D Management 15, 6676.

Binam, J.N., Tonye J., Wandji, N., Nyambi, G., Akoa, M. (2004) "Factors affecting the technical efficiency of small holders farmers in slash and burn agricultural zone of Cameroon". Food policy, 29:531-545.

Charnes, A., W.W. Cooper and E. Rhodes (1978), "Measuring the Efficiency of European Journal of Operation Research, 2, 429-444.

Chebil A., Frija A. and Abdelkafi B. (2010) 'Irrigation water use efficiency in collective irrigated schemes of Tunisia: determinants and potential irrigation cost reduction 'Contributed Paper presented at the Joint $3^{\text {rd }}$ African.

Association of Agricultural Economists (AAAE) and 48th Agricultural Economists Association of South Africa (AEASA) Conference, Cape Town, South Africa, September 19-23, 2010.

Chavas, J., Petrie, R., Roth, M., (2005). 'Farm household production efficiency: Evidence from the Gambia" American Journal of Agricultural Economics 87: 160-179. 
International Journal of Agriculture and Environmental Research

ISSN: 2455-6939

Volume: 06, Issue: 02 "March-April 2020"

Coelli T. (1996): "A Data Envelopment Analysis (Computer) Programme". Centre for Efficiency and Productivity Analysis. Department of Econometrics, University of New England. Armidale NSW 2351, Australia.

Coelli, T., Rahmans, T., C (2002). "Technical, Allocative, Cost and Scale Efficiencies in Bangladesh Rice cultivation. A non-parametric Approach". Journal of Agricultural and Resource Economics 48(2): 347-369.

Dhunguna. B.R., Nuthall, P.L., Nartea G.V., (2004). "Measuring the economic efficiency of Nepalese rice farms using DEA". The Australian Journal of Agricultural and Resource Economics 28(2):347-369

Farrell, M.J. 1957. The measurement of productive efficiency. Journal of the royal statistical society A120, 253-281.

Feder, G. and D. Feeny, (1991):Land Tenure and Property Rights : Theory and Implication for Development Policy World Bank Economic Review 5: 135-153

Federal Ministry of Water Resources (2004) "Review of The Public Irrigation Sector In Nigeria” Draft Report: Report No: 0009Rev1/TF/NIR/CPA/27277-2002/TCOT

Frija A.; J Buysse; S. Speelman; A. Chebil and V.H Guido (2010):" Effect of scale of Water User Association performance in Tunisia .Non-parametric Model for scale elasticity calculation". Contributed paper presented at the joint $3^{\text {rd }}$ African Association of

Agricultural Economists (AAAE) and $48^{\text {th }}$ Agricultural Economists Association of South Africa (AEASA) conference, Town, South Africa, September 19-23, 2010

Speelman S. ;J Buysse; Frija A.M. D'Haese and L D'Haese (2008) "Estimating the effect of water charge introduction at small-scale irrigation schemes in the North province of South Africa. Paper prepared for presentation at the $107^{\text {th }}$ EAAE Seminar "Modelling of Agricultural and Rural Development Policies". Sevilla, Spain, January 29th February 1st, 2008

Haji, J., (2006). "Production efficiency of small holder's vegetable-dominated mixed farming system in Eastern Ethiopians: A non-parametric Approach", Journal of African Economics 16(1): 1-27 
International Journal of Agriculture and Environmental Research

ISSN: 2455-6939

Volume: 06, Issue: 02 "March-April 2020"

Jose, A.G., Julio, B, and Manuel A. (2005). "MCDM farm system analysis for public management of irrigated agriculture".Paper presented at the $11^{\text {th }}$ congress of the EAAE, Copenhagen, Demark ,August 24-27, 2005.

Lovell, C.A.K. (1993), "Production Frontiers and Productive Efficiency" in Fried, H.O., C.A.K. lovell and S.S. Schmidt (Eds). The Measurement of Productive Efficiency, Oxford University Press New York, 3-67.

Malana N.M, H.M (2006): Benchmarking productive efficiency of selected wheat areas in Pakistan and India using Data Envelopment Analysis. Irrigation and Drainage, FAO, Rome.

Malano. H., Burton, M., and Makin. I, (2004). "Benchmarking performance in the irrigation and drainage sector: A tool for change".Irrigation and drainage 53:119-133

Maniadakis, N., Thanassoulis, E., (2004). A cost Malmquist productivity index. European Journal of Operational Research 154, 396-409.

Nwa, E.U. (1993). Irrigation research priority for Nigeria .Proceedings of a national seminar held at the University of Ilorin, 20-23, April, 1993. Ilorin Nigeria.

Organization for Economic Co-operation and Development (2012): Environmental outlook into 2050:The Consequences of Inaction: Key Findings on Water.

Somanathan, E., and R. Ravindranath (2006): "Measuring the Marginal Value of Water and Elasticity of Demand for Water in Agriculture", Economic and Political Weekly, June 30.

Speelman S. Marijke D.H.; Jeroen B; and Lue D. (2007). "Technical efficiency of water use and its determinants, Study at small-scale irrigation schemes in Northern-West Province, South Africa". Paper prepared for presentation at the 106th Seminar of the. EAAE. Pro poor development in low income countries: Food, Agriculture Trade and Environment.25-27 October 2007 - Montpelier, France.

Susanne M.S., Robert A.Y., and Grant E.C. (2004)" Determining the price responsiveness of Demands for Irrigation Water Deliveries Versus Consumptive Use. Journal of Agricultural and Resource Economics 29(2):328-345

Tom C. And J. Richardson (2008):Food price inflation: Causes and impacts congressional research service RS22859 
International Journal of Agriculture and Environmental Research

ISSN: 2455-6939

Volume: 06, Issue: 02 "March-April 2020"

United States Department of Agricultural Economic Research Research Service (2008): At http://www.usda.gov/Briefing/CPIFoodAnd Expenditures/consumerpriceindex.htm

Vega, J, Lee, D., Boisvert, R., Steenhuis, T., Proano M. and Poats, S., (2006). "Payments for watershed in Ecuador". Paper presented at the International Association of Agricultural Economists conference, Gold Coast, Australia. August 12-18, 2006.

Wadud, A., and White,B., (2006)."Farm household efficiency in Bangladesh: a comparison of stochastic frontier and DEA methods" Applied Economics, 32:1665-1673.

\section{APPENDIX}

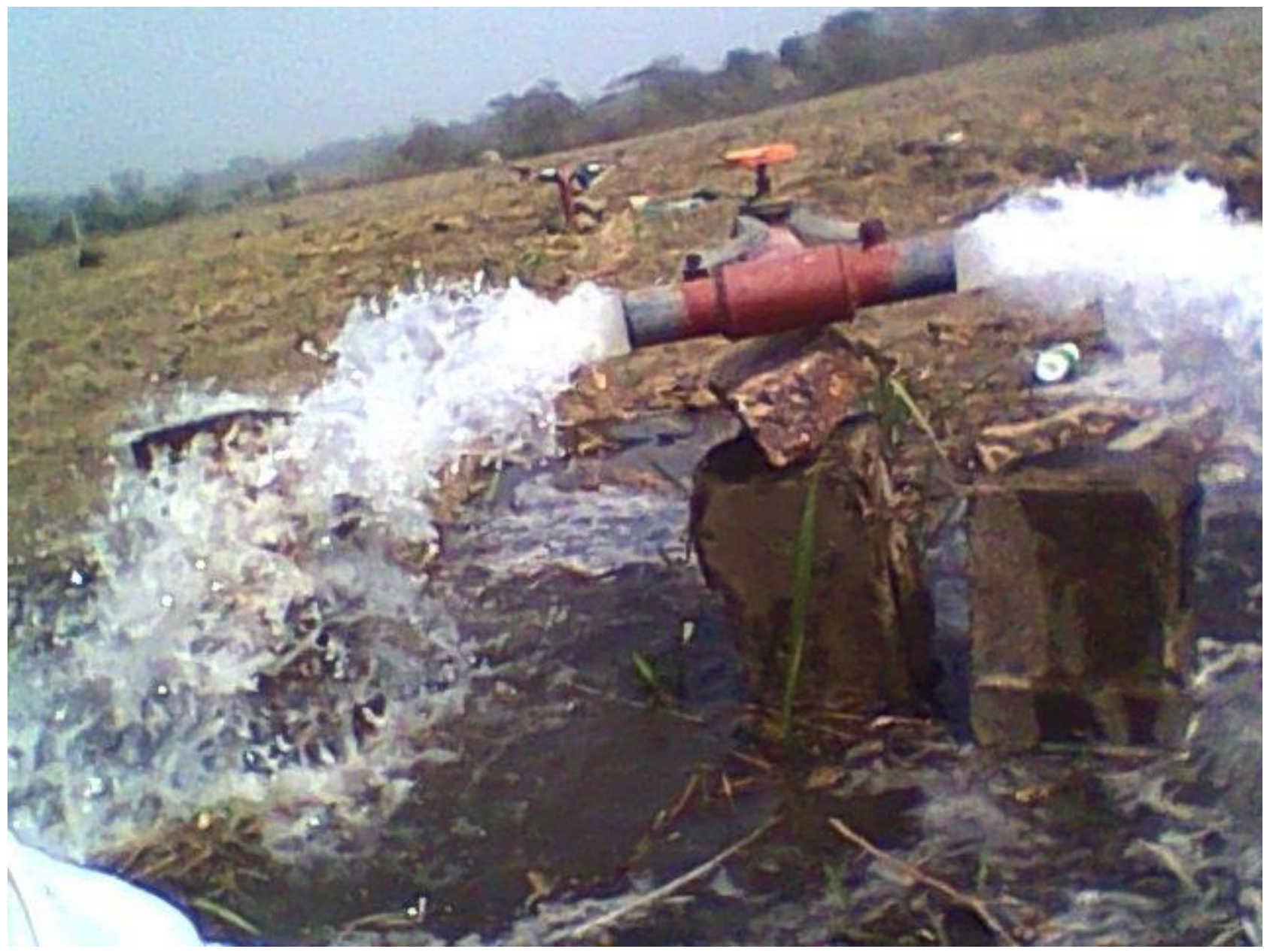

Central pump system, before hoses were inserted, at an irrigation scheme in the LNRBDA 